\title{
REDISCOVERY OF THE \\ CLIMBING FALSE BUCKWHEAT \\ IN SASKATCHEWAN
}

J. H. HUDSON, V. L. HARMS, Fraser Herbarium, Dept. of Plant Ecology, University of Saskatchewan, Saskatoon, and G. W. ARGUS, Botany Division, Museum of Natural Sciences, National Museums Canada, Ottawa.

In the late 19th century, before the extensive settlement and agricultural development of southern Saskatchewan, early botanical explorers reportedly found the native climbing false buckwheat (or wild buckwheat), Polygonum scandens L., to be widespread across the area. This is evidenced by the collections and reports of John Macoun and his son J. M. Macoun. In reference to this species in what is now Saskatchewan, the elder Macoun wrote: "Climbing over bushes at the Qu'Appelle Lakes, N.W.T. (J. M. Macoun). Forming almost impenetrable thickets near the sources of the Qu'Appelle, at Swift Current Creek, and at the eastern end of the Cypress Hills, N.W.T."5 Today, however, the species is not known in these cited localities even though it has been searched for there, and to our knowledge there have been no other collections of it from anywhere in Saskatchewan during the present century. Neither Fraser and Russell nor Breitung listed it for the province. 342 Boivin apparently included southern Saskatchewan in his range for the species only on the basis of the early Macoun collections from the Cypress Hills. 1 This primarily eastern North American species is presently known in Western Canada from Jackhead on Lake Winnipeg and Gilbert Plains in southern Manitoba, and Fort Saskatchewan and the vicinity of Edmonton in Alberta, on the basis of specimens present in the Ottawa herbaria (CAN and DAO). Macoun first reported it in Manitoba from "Winnipeg and NorthWest Angle Road, also Turtle Mountain, 49th parallel".5 Scoggan cited additional Manitoba records or reports from Matlock Beach on the southwest end of Lake Winnipeg, Shoal Lake, Rothwell, Brokenhead, and Spruce Woods Forest Reserve. 8 We are not prepared to comment regarding this plant's possible surviving range in Manitoba in contrast to its recorded range. However, it is noted that many of these records are from nearly a half century ago, if not more.

Recently we have found the climbing false buckwheat at two widely separated localities in eastern Saskatchewan. The collection data for these specimens are as follows: (1) South end of Doupe Bay of Jan Lake (lat. $54^{\circ} 53^{1 / 2^{\prime}} \mathrm{N}$, long. $102^{\circ} 49^{\prime}$ W) (T 68N, R $8 \mathrm{~W}$ 2nd $M$ ), climbing over rock outcrops and on sandy beach just west of resort area, 31 August 1975, V. L. Harms 23040 (SASK); and (2) Pipestone Creek Valley near Maryfield (lat. $49^{\circ} 53^{\prime} \mathrm{N}$, long. $\left.101^{\circ} 27^{\prime} \mathrm{W}\right)\left(\mathrm{SE}^{1 / 1} \mathrm{~s} \mathrm{Sec} .1, \mathrm{~T} 11 \mathrm{~N}\right.$, $\mathrm{R} 30 \mathrm{~W}$ 1st $\mathrm{M}$ ), climbing on western snowberry shrubs on heavily grazed brushy hillside, 15 July 1977, J. H. Hudson 3388 (SASK).

John Macoun's earlier collections from Saskatchewan are as follows: 


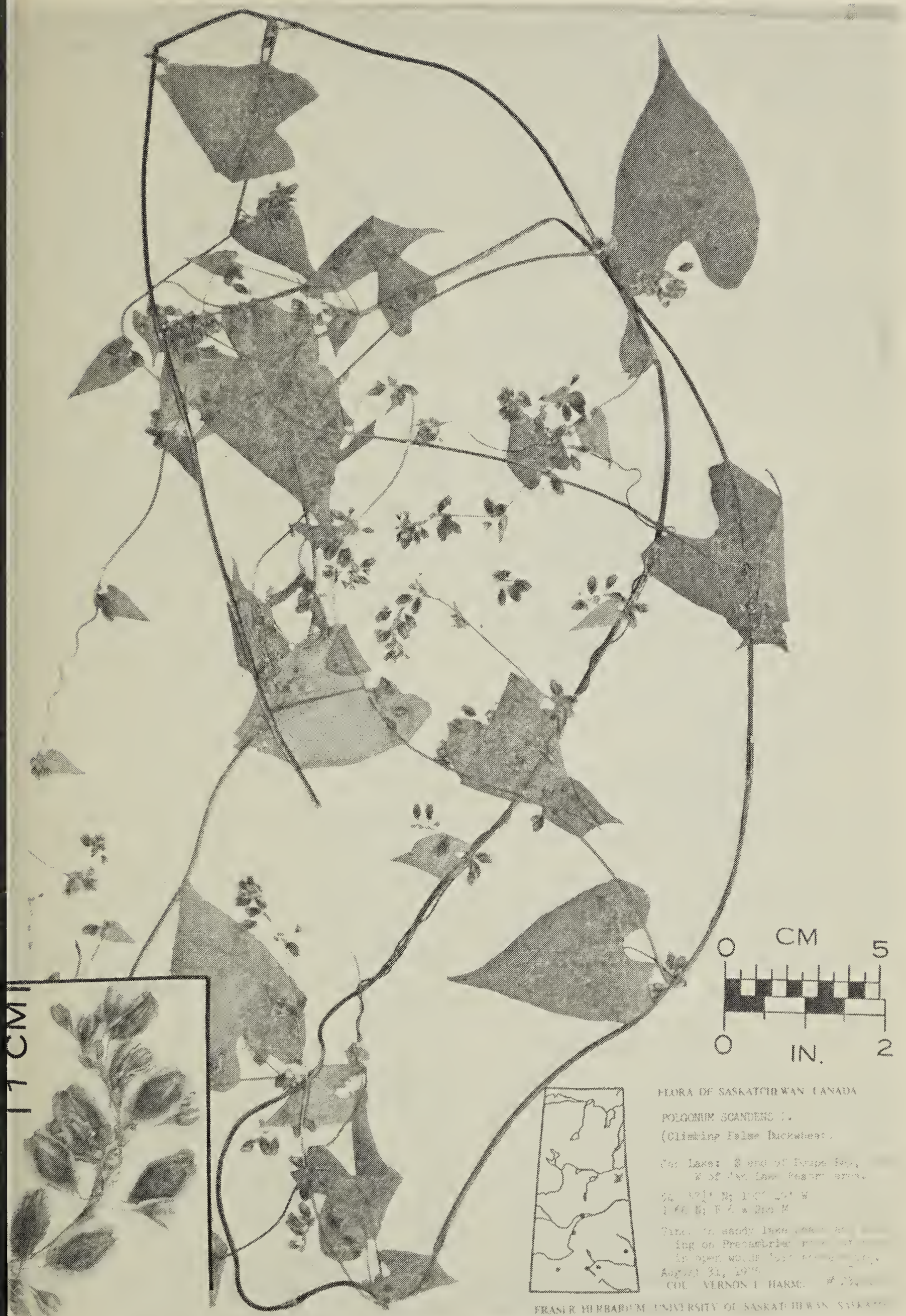

Figure 1: The Climbing False Buckwheat, Polygonum scandens. The inset shows a flowering-fruiting raceme enlarged. 
Cypress Hills, 27 August 1880, 150 ( $\mathrm{GH}$, photo DAO); Cypress Hills, in moist thickets, 29 August 1880, 23560 (CAN); Swift Current Creek, moist thickets, 4 September 1880, 23559 (CAN). The occurrences of this species at the Qu'Appelle Lakes, as reported by J. M. Macoun or from "near the sources of the Qu'Appelle" are not supported by specimens in the Ottawa herbaria. 5

What interpretation is to be given for the present rarity of this native buckwheat species in Saskatchewan, and its apparent absence from areas where it was reported as common nearly a century ago? Did the advent of white man's agriculture virtually eliminate this species in the province? Or more particularly, did the introduction of such Eurasian weed species as the black bindweed (wild buckwheat), Polygonum convolvulus $L$., take over its niche in naturally disturbed woodlands and shrublands here?

Our present collections indicate that this species still occurs in Saskatchewan, although these and the Alberta records could represent reintroductions rather than relictual stands. Reintroduction is suggested by the plant's occurrences in disturbed habitats and by its apparent sporadism. Yet a degree of weediness is to be expected in a native species characteristic of naturally disturbed sites. And sporadism would be expected of the surviving remnants of a native species that has had its range reduced by severe competitive pressures or by changed environmental conditions, especially at the edge of its range. It is impossible to answer the questions raised by the climbing false buckwheat in Saskatchewan until this elusive plant is sought elsewhere in the southern half of the province and informatior is obtained on its habitat anc possible competitors, especially the black bindweed.

The climbing false buckwheat Polygonum scandens, can be readily distinguished from the common in troduced wild buckwheat, $P$. con volvulus, by its conspicuously scarious-winged outer sepals surrounding the shining fruits fruiting pedicels over $4 \mathrm{~mm}$ ( $1 / 5$ inch) long, heart-shaped leaves with broadly rounded basal lobes, and perennial rather than annual habit (see Fig. 1). It can be distinguished from the native fringed black bindweed, $P$. cilinode Michx., by its broadly winged outer sepals, lack of a ring of long reflexed hairs on the younger nodes (at bases of the conspicuous sheaths), and simple raceme inflorescences rather than much-branched panicles. The climbing false buckwheat can be distinguished from the true buckwheats, Fagopyrum spp., by its racemose rather than corymbose inflorescences, by the fruits remaining enclosed within enlarging winged sepals rather than protruding from the unwinged, soon-withering sepals, by the embryos in the seeds being curved and marginal rather than central in the albumen with spiralling cotyledons, and by its perennial rather than annual habit.

The climbing false buckwheat, Polygonum scandens, is illustrated in Fig. 1. The known distribution of this species in Western Canada and adjacent United States, based upon literature reports and specimen records, is shown on the map of Fig. 2 , with the Saskatchewan records and reports dated. The United States records are taken from McGregor, Barkley, et al. 6 


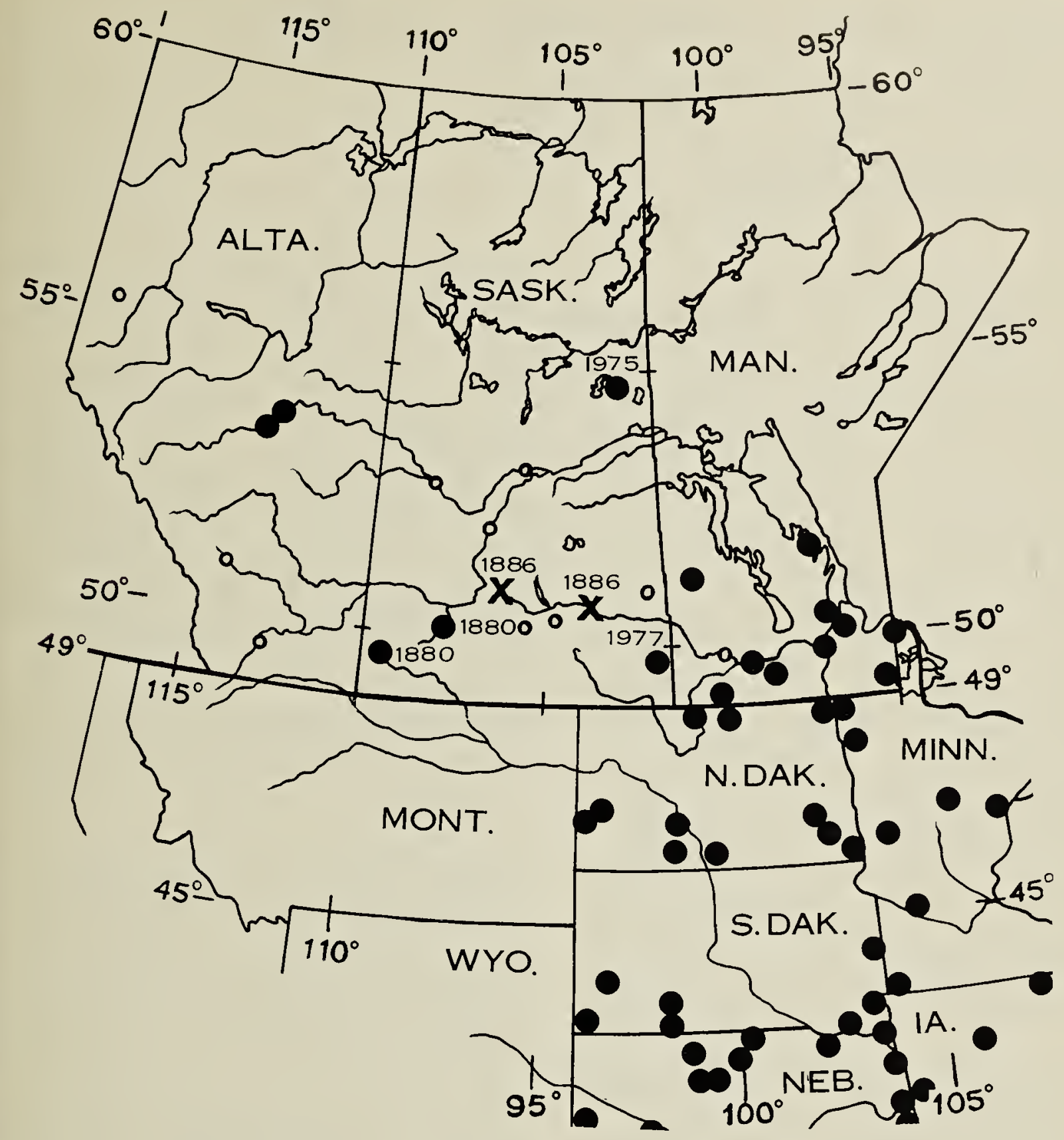

Figure 2: The Recorded Distribution of Polygonum scandens in Western Canada and Adjacent United States. For the Saskatchewan distribution, dots represent specimen ecords and the " $X$ "'s literature reports whose vouchers we have not seen. The Saskatchewan records are dated on the map.

BOIVIN, B. 1968. Flora of the Prairie Provinces, Part II - Digitatae, Dimerae, Liberae. 185 pp. (Reprinted from Phytologia, 16-18).

BREITUNG, A. J. 1957. Annotated catalogue of the vascular flora of Saskatchewan. The American Midland Naturalist, 58:1-72.

FRASER, W. P. and R. C. RUSSELL, 1944. An Annotated List of the Plants of Saskatchewan. University of Saskatchewan, Saskatoon, Saskatchewan. 1954. An Annotated List of the Plants of Saskatchewan. (Revised by Russell, R. C., G. F. Ledingham, and R. T. Coupland). University of Saskat- chewan, Saskatoon, Saskatchewan. $47 \mathrm{pp}$.

5MACOUN, J. 1886. Catalogue of Canadian Plants. Part III - Apetalae. Dawson Bros., Montreal. pp. 395-623.

6McGREGOR, R. L., T. M. BARKLEY, et al. 1977. Atlas of the Flora of the Great Plains. The lowa State Univ. Press, Ames, lowa.

7 MOSS, E. H. 1959. Flora of Alberta. University of Toronto Press, Toronto, Ontario. 546 pp.

8SCOGGAN, H. J. 1957. Flora of Manitoba. National Museum of Canada Bulletin No. 140.619 pp. 